\title{
EFFECT OF MOUTHRINSE CONTAINING IMMUNOGLOBULIN-Y ANTI-COMD STREPTOCOCCUS MUTANS + CHITOSAN ON QUANTITY OF SALIVARY STREPTOCOCCUS MUTANS IN CARIES AND CARIES-FREE SUBJECTS
}

\author{
ENDANG WINIATI BACHTIAR $^{1 *}$, ADANI NUR IMANINA ${ }^{2}$, RETNO D. SOEJOEDONO ${ }^{3}$, I. WAYAN TEGUH WIBAWAN ${ }^{3}$ \\ ${ }^{1}$ Department of Oral Biology, Faculty of Dentistry, Universitas Indonesia, Jakarta - 10430, Indonesia. ${ }^{2}$ Oral Science Research Center Faculty \\ of Dentistry Universitas Indonesia, Jakarta, 10430, Indonesia. ${ }^{3}$ Faculty of Veterinary Institute Pertanian Bogor, Indonesia, Bogor - 16680, \\ Indonesia. Email: endang04@ui.ac.id
}

Received 12 October 2018, Revised and Accepted 22 February 2019

\section{ABSTRACT}

Objective: Immunoglobulin-Y (IgY) anti-ComD Streptococcus mutans is expected to be an alternative passive immunization agent against caries. Chitosan which has an antibacterial property is expected to produce a better result. The aim of this study is to evaluate the effect of mouthrinse containing IgY anti-ComD S. mutans + chitosan on the quantity of salivary S. mutans in caries and caries-free subjects.

Methods: Each subject group was given IgY anti-ComD S. mutans mouthrinse and IgY anti-ComD S. mutans + chitosan mouthrinse. Mouthrinse was used twice a day for 6 days. Salivary S. mutans was cultured in TYS20B agar before and after treatment. The quantity of salivary $S$. mutans colonies was counted manually.

Results: This study showed that mouthrinse containing IgY anti-ComD S. mutans + chitosan has the potential to decrease the quantity of salivary S. mutans although not significantly.

Keywords: Caries, Chitosan, ComD protein, Immunoglobulin Y, Mouthrinse.

(c) 2019 The Authors. Published by Innovare Academic Sciences Pvt Ltd. This is an open access article under the CC BY license (http://creativecommons. org/licenses/by/4. 0/) DOI: http://dx.doi.org/10.22159/ijap.2019.v11s1.AR174

\section{INTRODUCTION}

The most common dental problem in Indonesia is caries, with a $90.05 \%$ prevalence according to the Household Health Survey 2004 [1]. This figure is concerning because oral and dental health is very important to support the health of the body.

Microorganisms having a major role in the etiology of caries include Streptococcus mutans [2]. S. mutans has a mechanism of interspecies (quorum sensing) communication, involving the ComD receptor on the cell surface [3]. Inactivation of the $C o m D$ gene, which is a gene encoding the ComD receptor that is present on the cell surface, decreases the potential of $S$. mutans to form colonies, and interact with other bacteria $[3,4]$. S. mutans can be found in saliva, and their numbers are related to caries activity in individuals [2].

Research to find alternative methods of caries prevention continues, such as by active and passive immunization. However, because active immunization with the administration of whole $S$. mutans cells would cause side effects of cross-reaction with cardiac muscle tissue [5], researchers are attempting to develop anticaries passive immunization methods [6].

Immunoglobulin-Y (IgY), obtained from chicken eggs, is an inexpensive and easily obtainable source for the production of specific antibodies [7]. IgY does not harm the host, and the presence of IgY in host saliva has no side effects [8].

Many studies identified the effects of IgY on S. mutans antigen. Hatta et al. developed an IgY anti-S. mutans mouthwash and reported decreased numbers of $S$. mutans in saliva [9]. Anggraenialso studied the use of IgY in a gel preparation in Sprague-Dawley rats and reported a significant decrease in $S$. mutans in rat saliva [10]. In addition, Chismirina investigated the effect of IgY as an inhibitor of S. mutans adhesion and reported a decrease in $S$. mutans colonization on tooth surfaces [11].
Bachtiar produced the specific IgY ComD S. mutans that interfered with the $S$. mutans bacterial communication system. DNA vaccine could be used as an innovative strategy to control the colonization of cariescausing bacteria [12].

The addition of chitosan, which has antibacterial, antifungal, biocompatible, and flexible characteristics, was expected to yield better results than IgY anti-ComD S. mutans alone. As noted by Henrietta, IgY anti-cell $S$. mutans and chitosan could suppress the amount of $S$. mutans in biofilms. In addition, chitosan also could act as a preservative $[13,14]$.

Conflicting results could be seen in a study by Febyani, in which autoaggregation of $S$. mutans serotypes c and e actually increased after exposure to IgY anti-S. mutans and chitosan [15]. Similar results also were reported by Septryani, who showed that the gel containing the chitosan-nano silver composite with IgY anti-S. mutans serotype c actually decreased the effectiveness of IgY anti-S. mutans in inhibiting the formation of $S$. mutans biofilm [15]. Therefore, to correct the deficiencies of previous studies, we studied the effect of a mouthrinse containing IgY anti-ComD S. mutans + chitosan on the quantity of salivary S. mutans.

\section{METHODS}

After obtaining ethical clearance, 24 FKG UI students with and without caries provided signed informed consents to participate. Subjects were divided into two groups given mouthwash containing IgY anti-ComD S. mutans (Group 1) and IgY anti-ComD S. mutans + chitosan (Group 2).

The mouthwash was made by adding IgY anti-ComD S. mutans to total care non-alcohol mouthwash to a concentration of $0.01 \%$ and chitosan to a concentration of $2 \%$ in a $120 \mathrm{~mL}$ mouthwash bottle. Before treatment, $1 \mathrm{~mL}$ of the subjects' saliva was collected. Subjects then were asked to rinse 2 times a day in the morning and evening for $30 \mathrm{~s}$ using $10 \mathrm{~mL}$ of mouthwash for 6 days. After the treatment period, $1 \mathrm{~mL}$ samples of saliva were collected again. 
Each saliva isolate then was centrifuged for $2 \mathrm{~min}$ at 13,000 g pressure. Then, the salivary supernatant was removed, and the remaining pellet was added to $1 \mathrm{~mL}$ phosphate-buffered saline and pipetted. A total of $15 \mu \mathrm{L}$ were cultured from each sample in duplicate on medium agar TYS20B and incubated at $37^{\circ} \mathrm{C}$ for $3 \times 24 \mathrm{~h}$. Bacterial colonies of S. mutans were calculated manually.

The data then were analyzed statistically. Data in group 1 had a normal distribution and were tested with the paired t-test. Data in Group 2 had an abnormal distribution and were tested with the Wilcoxon signed-rank test. The numbers of bacterial colonies in both groups were compared and tested by an independent t-test. The statistical significance level was set at $0.05(\mathrm{p}=0.05)$.

\section{RESULTS}

Mean values decreased in both groups after treatment (Figs. 1 and 2). The paired t-test and Wilcoxon signed-rank test in Groups 1 and 2, respectively, revealed no significant difference in mean numbers of S. mutans colonies between before and after treatment $(\mathrm{p}=0.218$ and $\mathrm{p}=0.583$, respectively). The decrease in $S$. mutans colonies was greater in Group 2.

\section{DISCUSSION}

After the discovery of the association of $S$. mutans with dental caries, various studies have been conducted to determine alternative caries prevention methods using antibacterial agents. We used IgY antiComD S. mutans as antibodies and chitosan, which had antimicrobial effects.

IgY inhibits caries development by inhibiting $S$. mutans colonization. IgY works by binding to $S$. mutans antigens and neutralizing the

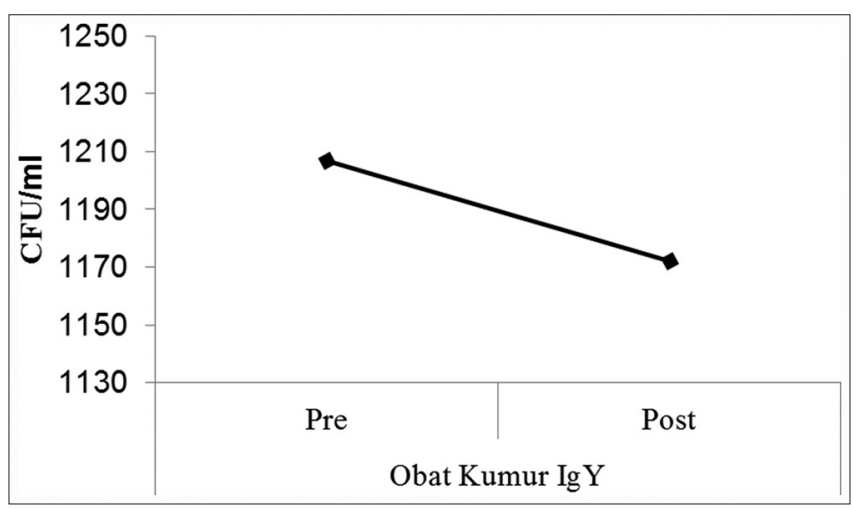

Fig. 1: Mean number of Streptococcus mutans colonies group in Group 1 before and after treatment

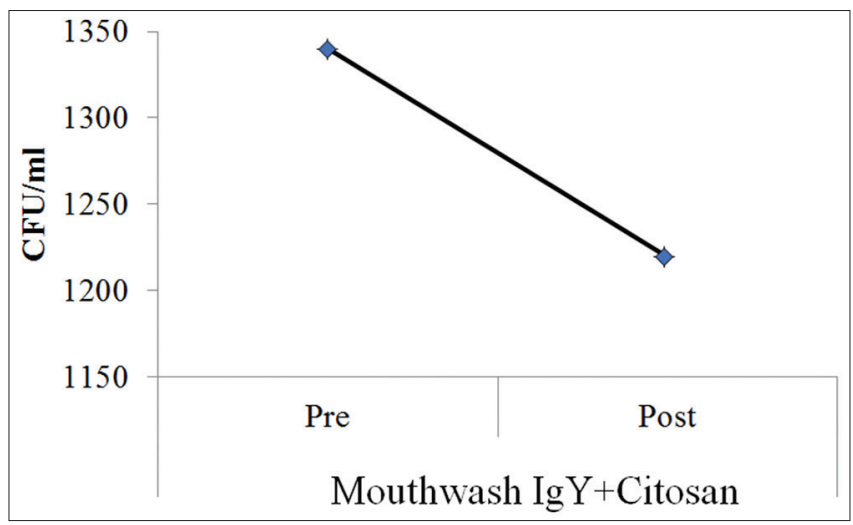

Fig. 2: Mean number of Streptococcus mutans colonies in Group 2 before and after treatment biological activity of the antigen. Specific IgY antigen I/II given locally may bind S. mutans because the I/II antigen resides on the cell wall [16]. This causes the $S$. mutans bacteria to fail to proliferate. In addition to its antigens, virulence of $S$. mutans bacteria also involves intercultural and interspecies communication mechanisms (quorum sensing). Communication of $S$. mutans involves the role of the autoinducer molecule and its receptor (ComD) on the cell surface [4]. IgY antiComD S. mutans interferes with this communication system to control the colonization of the bacteria that cause caries. On the basis of the inactivation ComD study of Loo et al., the gene encoding ComD decreases the ability of $S$. mutans to colonize and interact with other bacteria [4]. The IgY anti-ComD S. mutans used in this study were produced by Bachtiar [12]. We used chitosan because, in addition, its antibacterial properties, chitosan also can bind well to proteins, in this case, IgY anti-ComD S. mutans [17]. In addition, Costa et al. showed that chitosan is capable of interfering with $S$. mutans adhesion and biofilm formation and capable of decreasing mature biofilm defenses by as much as $94 \%$ [18]. Other chitosan benefits are that it is nontoxic, biodegradable, and biocompatible [19].

Samples were taken from the saliva of the subjects because the number of $S$. mutans bacteria in saliva described the number of bacteria in the biofilm and was related to caries levels in adults [20]. In this study, a mouth rinse was chosen because it was used commonly in caries prevention. We wished to determine the effect of combined IgY antiComD S. mutans + chitosan on the amount of $S$. mutans saliva in subjects with and without caries. After treatment, the number of $S$. mutans in the saliva decreased in both test groups. A larger decrease occurred in Group 2 compared with Group 1.

Our results are supported by those of several studies. Studies on the effects of IgY in mouthwash conducted by Hatta et al. demonstrated a decrease in the ratio of $S$. mutans percentage per total streptococci to saliva after subjects used a mouth rinse containing IgY and $10 \%$ sucrose twice in $4 \mathrm{~h}$ [9]. In the same study, subjects who used a nonsucrose IgY mouth rinse for 6 days experienced a decrease in S. mutans salivary levels that were not statistically significant. Nguyen $e t$ al. also reported a significant decrease in the number of $S$. mutans in the saliva of subjects given lozenges containing Gtf-specific IgY [21]. Smith et al. reported that specific Igb GbpB may provide protection from the mutagenicity of S. mutans and prevent caries [22]. Their research showed that molar caries levels in mice given GbpB-specific IgY decreased significantly within 78 days, and this decrease was related to the amount of IgY administration. In addition, the effect of IgY on the amount of $S$. mutans in saliva also was investigated by Yonezu et al., indicating that topical application of IgY significantly decreased the amount of S. mutans in saliva [23].

Our study provided an overview of the effect of a mouthwash containing a combination of IgY anti-ComD S. mutans + chitosan on the number of $S$. mutans saliva in subjects with and without caries. Our results showed no significant difference in the decreased numbers of $S$. mutans in subjects who used a mouth rinse with and without chitosan. Further research must be done to determine the effectiveness of chitosan as an anti-ComD IgY binding agent in the form of mouthwash and to determine the concentration of IgY antiComD S. mutans and chitosan effective for use as an alternative to caries prevention.

\section{CONCLUSIONS}

Mouthwash containing a combination of IgY anti-ComD S. mutans + chitosan could decrease the number of $S$. mutans in saliva, but not significantly. More research is needed on the concentration of IgY anti-ComD S. mutans and chitosan effective to decrease the amount of S. mutans in saliva significantly.

\section{CONFLICTS OF INTEREST}

Declared none. 


\section{REFERENCES}

1. Departemen Kesehatan. SKRT 2004. Jakarta: Badan Litbangkes; 2005.

2. Mount GJ, Hume WR, Ngo HC, Wolff M. Preservation and Restoration of Tooth Structure. Queensland: Knowledge and Book Software; 2005.

3. Li YH, Tang N, Aspiras MB, Lau PC, Lee JH, Ellen RP, et al. A quorum-sensing signaling system essential for genetic competence in Streptococcus mutans is involved in biofilm formation. J Bacteriol 2002;184:2699-708.

4. Loo CY, Corliss DA, Ganeshkumar N. Streptococcus gordinii biofilm formation: Identification of genes that code for biofilm phenotypes. J Bacteriol 2000;182:1374-82.

5. FerrettiJJ, Shea C,HumphreyMW.Cross-reactivity of Streptococcusmutans antigens and human heart tissue. Infect Immun 1980;30:69-73.

6. Smith DJ, Taubman MA. Vaccines Against Dental Caries Infection. New Generation Vaccines; 1997. p. 914-30.

7. Kuroki M. Oral passive immunization using chicken egg yolk immunoglobulins against bovine rotavirus and coronavirus infection. Rec Res Dev Virol 1999;1:95-106.

8. Larsson A, Bålöw RM, Lindahl TL, Forsberg PO. Chicken antibodies: Taking advantage of evolution - a review. Poult Sci 1993;72:1807-12.

9. Hatta H, Tsuda K, Ozeki M, Kim M, Yamamoto T, Otake S, et al. Passive immunization against dental plaque formation in humans: Effect of a mouth rinse containing egg yolk antibodies (IgY) specific to Streptococcus mutans. Caries Res 1997;31:268-74.

10. Anggraeni. Prospek Gel Imunoglobulin-Y. Anti-Streptococcus mutans Sebagai Bahan Imunisasi Pasif Anti Karies: Analisis Sifat Biologis Gel Imunoglobulin-Y Anti Streptococcus mutans dan Pengaruhnya Terhadap Proses Karies Pada Tikus Sprague Dawley [Disertasi]. Indonesia: Universitas Indonesia; 2010.

11. Chismirina S. Efek Imunoglobulin Y Sebagai Antiadhesin Pada Pembentukan Biofilm Oleh S. mutans (Serotipe c,e,f) dan S. sobrins (Serotipe d) Secara in vitro. Indonesia: Universitas Indonesia; 2006.

12. Winiati BE. Pembuatan Kemasan dan Uji Anti Karies IgY Kuning Telur sebagai Suplemen Obat Kumur, Pasta Gigi dan Topikal Aplikasi; 2011.

13. Alysia H. Efek Pemberian Susu Kedelai yang Diperkaya dengan Kitosan IgY Anti-Streptococcus mutans pada Tikus Malnutrisi: Evaluasi Pada
Pembentukan Biofilm Dental dan Berat Badan [Skripsi]. Universitas Indonesia; 2009.

14. Razali N. Evaluasi Persistensi Immunoglobulin Y anti S. mutans pada Saliva Tikus Malnutrisi Setelah Diberi Susu Kedelai Yang Diperkaya Dengan IgY anti S. mutans dan kitosan [Skripsi]. Universitas Indonesia; 2009.

15. Febyani N. Efek Imunoglobulin Y (IgY) anti Streptococcus mutans dan Kitosan Terhadap Autoaggregasi Mutans Streptococci Serotip c, d, e, dan f [Skripsi]. Universitas Indonesia; 2009.

16. Dutta PK, Dutta J, Tripathi VS. Chitin and Chitosan: Chemistry, Properties, and Application. Allahabad: Department of Chemistry, Motilal Nehru National Institute of Technology; 2004.

17. Choi BK, Kim KY, Yoo YJ, Oh SJ, Choi JH, Kim CY, et al. In vitro antimicrobial activity of a chitooligosaccharide mixture against Actinobacillus actinomycetemcomitans and Streptococcus mutans. Int J Antimicrob Agents 2001;18:553-7.

18. Costa EM, Silva S, Tavaria FK, Pintado MM. Study of the effects of chitosan upon Streptococcus mutans adherence and biofilm formation. Anaerobe 2013;20:27-31.

19. Tarsi R, Corbin B, Pruzzo C, Muzzarelli RA. Effect of low-molecularweight chitosans on the adhesive properties of oral streptococci. Oral Microbiol Immunol 1998;13:217-24.

20. Chia JS, Chang WC, Yang CS, Chen JY. Salivary and serum antibody response to Streptococcus mutans antigens in humans. Oral Microbiol Immunol 2000;15:131-8.

21. Nguyen SV, Icatlo FC Jr., Nakano T, Isogai E, Hirose K, Mizugai H, et al. Anti-cell-associated glucosyltransferase immunoglobulin Y suppression of salivary mutans streptococci in healthy young adults. J Am Dent Assoc 2011;142:943-9.

22. Smith DJ, King WF, Godiska R. Passive transfer of immunoglobulin $\mathrm{Y}$ antibody to Streptococcus mutans glucan binding protein B can confer protection against experimental dental caries. Infect Immun 2001;69:3135-42.

23. Yonezu T, Sano Y, Kumazawa K, Fujita H, Kojima T, Shintani S, et al. Effects of Topical Application of IgY on Salivary Streptococcus mutans. Paper Presented at: $9^{\text {th }}$ World Congress on Preventive Dentistry; 2009. 